


$$
\begin{aligned}
& \text { ORIIL- }-5844 \\
& \text { DES2 } 014570
\end{aligned}
$$

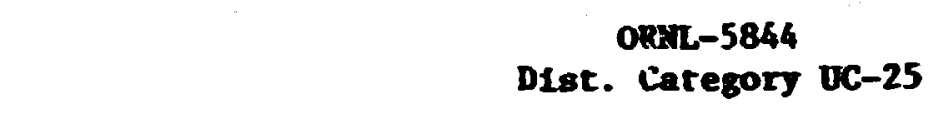

Contract No. W-7405-eng-26

VETALS AD CERAMICS DIVISIOA

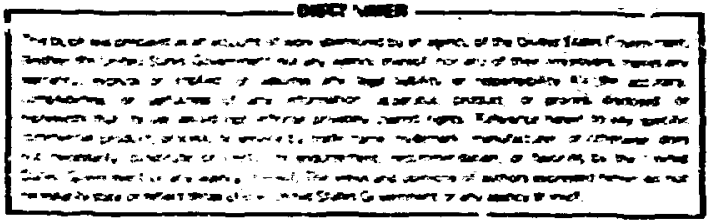

A REVIEN OF RECENT IRRADIATION-CREgP RESULTS

by

W. A. Coghlan

Date Published - May 1982

DAK RIDGE NATIONAL LABORATORY

Dak R1dge, Tennessee 37830

operated by

UNION CARBIDE CORPORATION

for the

DFPARTMENT OF ENERGY 
TABLE OF CONIENTS

PAGE

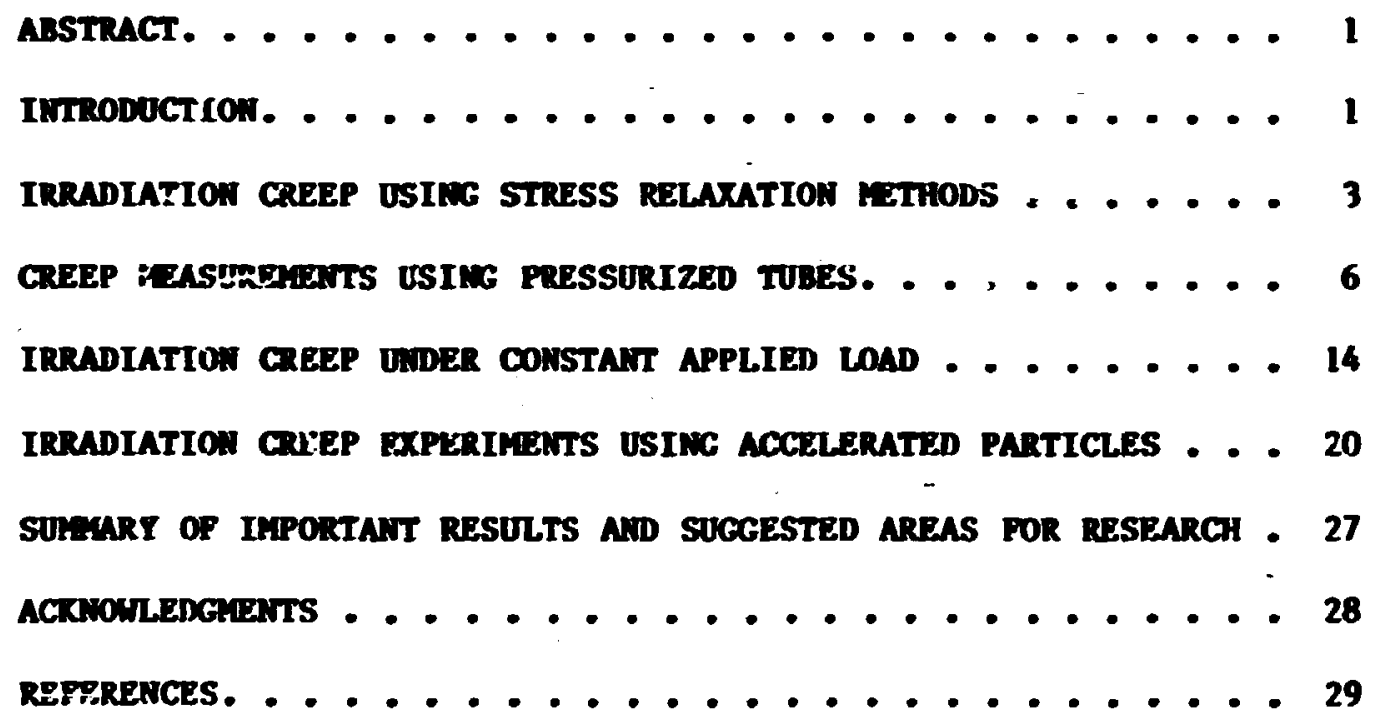




\title{
A REVIEN OF RECENT IRRADIATION CREEP RESULTS
}

\author{
H. A. Coghlan
}

\section{ABSTRACT}

\begin{abstract}
Materials deform faster under stress in the presence of irradiation by a process known as irradiation creep. This phenomenon is important to reactor design and has been the subject of a large nuber of experimental and theoretical investigations. The purpose of this work is to revien the recent experimental results to obtain a sumary of these results and to deternine those research areas that require additional information. The investigations have been classified into four subgroups based on the different experimental wethods used. These four are: (1) Irradiation creep using stress relaxation methods, (2) creep measurements using pressurized tubes, (3) Irradiation creep from constant applied load, and (4) Irradiation creep experinents using accelerated particles. The sinilarity and the differences of the results from these prhods are discussed and a surmary of inportant results and suggested areas for research is presented. In brief, the imnteant results relate to th. dependence of creep on swelling, temperature, str sse state and alloying additions. In each of these areas new results have been presented and new questions have arisen which require further research to answer.
\end{abstract}

\section{INTRODUCTION}

Irradiation nreep is radiation induced plastic deformation of a vaterial. During the last decade or $s 0$, there has been considerable effort to measure and understand this phenomenon. Creep rates of materials important to fission reactor desikpers have been measured as a function of applied stress, cemperature, and irradiation fluence. As we shall see, these studies have focused on a few austentic stainless steels and some zirconfum alloys. The purpose of this report is to review and sumarize experimental results with emphasis on work published since 1977. Prior to this date, several reviews had been published. 
In $19 \%$, llesice: $h^{l}$ published a broad view of the early irradiation cresp reseitis. he included data describing stress, temperature, and thence dependenctas for a broad range of cubic, noncubic, fissile, and noiff-alle sals. In addition, he reviewed the theoretical explonation off... : at that time. There have been a number of nore recent reviews a.il I cail your attention to three of these. Gitcus ${ }^{2}$ Include: a ions chapter on irradiation creep in his book. This macerial fucluiez a discussion of the theoretical models available at that time.? $n$ :977, Straalsund ${ }^{3}$ collected the available data meisired for iriadiation creep in stainless steels, the meterial chosan to be the s-cuctural material for breeder reactors. Finally, I refer you t, il.c. review of Irradiation creep published by Harries ${ }^{4}$ in 1977. In $: 3,18$ paper the various wethods for measuring Irradiation iseep are desiribed along with a discussion of the advantages and disadvant.ajes of eact. A]so Harries has rolated the experimental neasureasirg to theoretical explanations in an attenpt to provide support for or L.; discredit each of the models. He also presented a l1st of sugg:sted experiments to answer some of the remaining unanswered quest1crip.

The measurement of Irradiation creep has not been easy. At temperatcics and atrewses where thermal creep rates are very low and irrajiatica creep can be measured independently, the irradiation creep rater ate ?ow and difficult to measuie. The radlation environment requir.d finr the study is a very hostlle environment for materials; and, ar sesult, tit is difficult to design testing machines which will coar"te reliahly and accurateiy enough to make the masurements. As a resu't of these difficulties, there have been a wide variety of experimeñ: 11 techuljues developed to measure irradiation creep. Each of thre: has its own advantages and disadvantages, and each has providen isef al information. A dificulty develops, however, when resilizi from one technique are compared with results measured using arother terhniqup. In some cases these comparisons can be made on reascnahle theoretical prounds while in others no direct comparison is p.rasinle. 
In the following overview, the recent results have been divided Into four groups based on the experimental technique used tc irradiate the sample and to apply the stress. Data is discussed under the titles - Irradiation Creep Using Str-ss Relaxation Methods; Creep Yezsurements Using Pressurized Tubes; Irradiation Creep From Constant Applied Load; and Irradiation Creep Experiments Using Accelerated Particles. In the course of preparing this review, I have attempted to deternine whet the wot imortant findings have been and wat the wost important questions left unanswered are. The report will close with a sumary of this inforwation.

\section{IRRADIATION CREEP USIRG STRESS RELAXATION METHODS}

Various stress relaxation techniques for measuring irradiation creep have beer. ssed since irradiation creep was first discovered. The wany forns of this technique have several characteristics in comson. The samples are loaded to some inftial stress and are placed in the reactor environment. The relayation of this stress occurs through deforwation of the sample, and this deformation is observed by measuring the rewaining stress in the samples after Intervals of irradiation. The continuing relaxation of the stress results from continuing creep strain.

The method is relatively simple, utilizes small samples, and requires minimus experimentsl sophistication. However, it is not whout problems. The most obvious and limiting one is that the strain is limited to an elastic deflection (1.e., strains from about $10^{-6}$ to $10^{-3}$ ). These small strains often occur during primary creep, and the experimental results are often only measurements of this primary creep. The effect of irradiat ion on this creep can be obtained hy comparison of in-reactor relaxation with out-of-reactor results. From such experiments, it is easy to show qualitatively that irradiation enhances creep but quantitative description 18 difficuit.

Over the last 15 years, several investigators have analyzed stress relaxation experimente. In 1977 , Povolo 5 published an analysis of stress relaxation through creep. To describe the strain rate, he chose 


$$
\dot{\varepsilon}=K\left(\sigma-\sigma_{i}{ }^{n} s ! t\right),
$$

where the tine dependent primary creep is included in $f(t)$ which is often assuned to be proportional to $t^{\text {It. }}$. Most early resulti can be derived as special cases of this goneral one. Povolo shoured how the material constants, $k, n$, and $m$, can be obtained from analysis of experimental stress relaxation data for tensile, bending, and corsion stress relaxat lons. There are two obvious linitations, bovever. First, for tl:is analysis enough data mst be caken to evaluate the $t$ Ine dertvatives of the relaxed stress. Sesond, for $f(t) \neq t^{m}$ more information about the time dependence of prinary creep ast he known to extract the ocher creep paraneters. In 1978, Povolo and Toscano ${ }^{6}$ derived sinilar results assualng strain hardening instead of clae hardentng. Recently, thls last analysls was shown to give a wuch betrer fit than the time hardening analysis for thernal relaxation of stress-relleved fid cold-worked 7.1rcaloy-4 at $400^{\circ} \mathrm{C}$. In spite of these difficulties, a number of recent investigailons have been conducted which have provided useful information.

Renfield et al.8 1 rradiated 78 speciwens of $20 \%$ a 316 stainless steel In EBR-II at $370^{\circ} \mathrm{C}$. The samples were stresste in four-point bending from 28-345 MPa and were examined after Irradiation to $2 \times 10^{25} \mathrm{r} / \mathrm{m}^{2}$. Sowetime during thls exposure, strain occurred which caused a relaxation of from $40-60 \%$ of the applled stress. The relaxation strain under irradiation is abouc four imes that measured for a thermal stress relaxation. The result.s were compared to come predinted by a low fluence design equation, and the measured creep was somewhat 1 ess than the predict.ed creep.

Stress relaxation of loaded springs has been used to measure the Irradiation creep of Nimoric 80 (ref. 9) and Inconel X750 (ref. 10). After an Irradiation period, the remaining stress on the springs can be measured by deforming the spring slightly and masuring the load required. A significant difference in tinls method from the bent. bean 1s that. the applled stress is nearly pure shear and is uniform across the sample crnss section. The results are reported for a very linited 
range in teaperature and 8 tress, but they show that these materials creep at wch the same race as stainless steel.

In all the results described above, the total strain available to the experiment is small, and 30 it is not possible to measure irradiation creep at high fluences and high strain rates. A group of investigators ${ }^{11-14}$ at the Haoford Engireering Development Laboratory (HEDL) have devised two stress-relaxation techniques to overcone this linitation based on the idea of using preirradiated materizl to make stress-relaxation specimens. In the first method, strips of irradiated type 304 stainless steel duct material were lnaded by urapp:ng thew around andrel. After re-irradiation, the creep strain was deternined by measuring the curvature of unloaded stripg. In the second wethod, a slit was cut in sections of irradiated pressurized tube sauples of $20 \mathrm{z} \mathrm{CH} 316$ stainless steel. The samples were then loajed elastically by inserting wedges in the slits. The stress on the samples was deterined at intervals by measuring the force required to spen the slit which decreases as creep causes the elastic stress to relax.

The chief advantage of the mardrel loading technique is that it wakes it possible to study irradiation creep in samples of aterial cut frow structural parts having a high irradiation dose. Creep measurements have been reported on type 304 stainless steel Il, 13 samples naving nearly tha highest neutron exposure of any materiai. The creep rate appears to have a component that is proportional to the owelling rate of the material. After a neutron expostre of $5 \times 10^{26} \mathrm{n} / \mathrm{m}^{2}$, both the swelling rate and the creep rate increased sharply.

The split tube technique akes ir. possible to tudy continued irradiation of pressurized zube specimens under a variety of different Irradiation condicions. The results reported for continued creep under a change in temperature 12 and under a change In applied stresa 14 are of particular importance to fusion reactor design. A temperature change of $40-100^{\circ} \mathrm{C}$ appears to have very little effect on the mensurad creep rate of $20 \%$ CW AISI 316. The samples continue to creep at much the same rate as they had at the original irtadiation temperatures. A change In applied atress, on the other hand, appears to cause innediate transient creep that is independent of prior stress history. 
This trausient strain involves primarily thermal processes because it does not occur if the samples are annealed for $50 \mathrm{~h}$ at the new stress In the absence of Irradiation.

Recently, Causey and others 15 isve reported some in-reactor stress relaxation results that eay also be of interist to fusion reactor designers. They reported in-reactor stress relaxation of bent beans of 1: different materials at 67 and $300^{\circ} \mathrm{C}$. In all but one of the cases reported, the creep rate at $67^{\circ} \mathrm{C}$ was greater than-or-equalto that at $300^{\circ} \mathrm{C}$. These results are consistent with some other early results but are not readily explained using any of the known oodels.

\section{CREF.P REASUREAENTS USING PRESSURIZFD TUBES}

A second gevera: method for measuring irradiation creep is the measurements of the Increase in diaveter of pressurized tubes under irradiation. Ttis method has the advantage that the specinens are relatively gall and simple to construct. The loading is biaxiai and often reflects the actual loading expected for the materials in service. However, this biaxial loading is also a difficulty because It nakes it difficult to comare the results with those measured in standard tensile tests.

In tis review, Harries 4 discusses the problems associated with directly applying the Soderberg formalisn to convert the result from all types of tests to effective stress and strain. The chief complication artses because of an apparent relationsht; between avelling and creep. If the eaple does not maintain constant volume during creep, straightforward application of the Soderberg formaliso is in error. Since the relationship between creep and arelling is the subject of current research, comparinon of blaxial, uniaxial, and shear creep results should be regarded with ckution. With these gdvantages and disadvantages in aind, I will now present a sumary of the nost recent published resulte.

Waltere and coworkers ${ }^{16-20}$ have analyzed the creep data from 130 pressurized tubes which were irradiated in four cubassemblies in EisRII. The first subassably was composed of 19 tubes mide from solution 
annealed $304 \mathrm{~L}$ stainless steel capsules irradiated at $385^{\circ} \mathrm{C}$ with the pressure generated hoop stresses from 0-191 MPa. The renaining three subasseabl'es contained 111 tuives ade from 316 stainless steel in several different wallurgical condit_ons. Two of these subassemblies were irradiated at $400^{\circ} \mathrm{C}$ and contained lellium pressur? to generate hoop stresses from 0-345 $\mathrm{ma}$. The third was irradiated at $550^{\circ} \mathrm{C}$ with slightly lower stresses. Host of the 316 stainless tubes were in three different metallurgical conditions - 202 cold-worked, solut: on annealed, and capsules aged for $216 \mathrm{~h}$ at $704^{\circ} \mathrm{C}$. This last condition, called HID by the authors, results in the preclpitation of large metal carbide particles which causes a large change in arelling and creep behavior. In addition to these t. bes, analysis was made of some stainless steel fuel cladding that was irradiated in ERR-II and Rhapsodie at temperatures fros $400-600^{\circ} \mathrm{C}$.

The analysis of all these samples was firected to.rard answering questlons in two min arcas. First, an attempt was made $t$ ) measure the stress dependence on swelling and to determine the relationship between swelling and creep. 16-18 Second, the authors tried to deterane the role that metal carb!de precipitation plays in enhancing swelling and creep in these materials.19,20 Although we shall see that the questions are not completely answered, several valuable cbrervations were made.

The 304L stainless steel capsules were irradiated the longest; hence, the inforwation 18 known to higher doses. In addition, the tubes in this experiment are :ong enough to sample a neutron flux variation of a factor of 60 and te experience a variation in average neutron energy from 0.077 to $0.61 \mathrm{MeV} .16$ No effect on deformation, elther creep or swelling, was weasured for these variatons In flux and energy. However, both the creep rate and owelling rate Increased with fluence. The atress dependence of the creep for stresses up to $191 \mathrm{MPa}$ is IInear, and at the highest stress the total deformotion is approxinately one third owelling and two thirds creep. PIgure I has been replotted from Ref. Is and shows the total deformation at $191 \mathrm{MPa}$ along with the isformation measured in an unpreseurfized tubc. The dashed curve ts the irradiation creep deternined by 


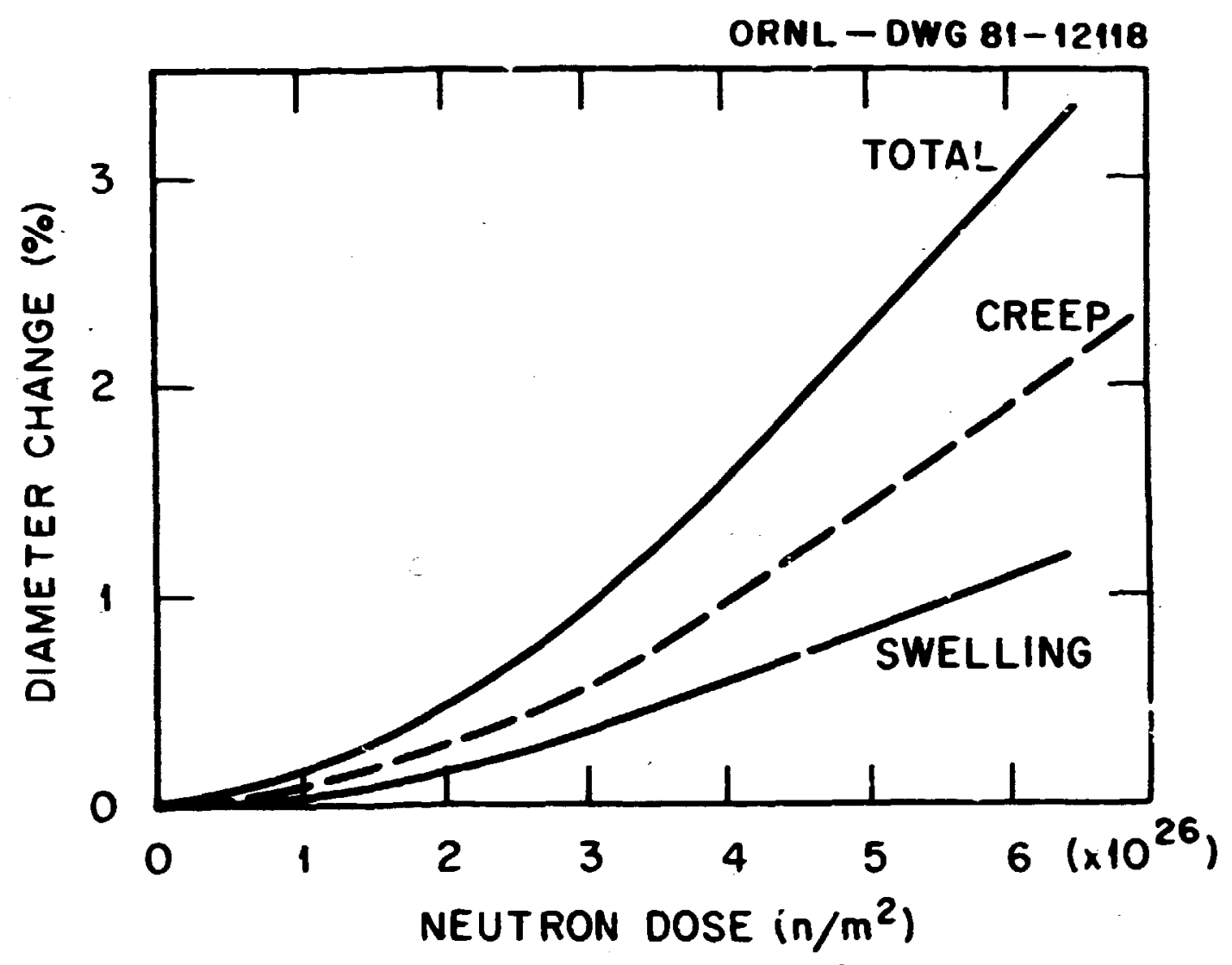

F1g. 1. Creep, arelling and total diameter changes as a function of neutron fluence for type $304 \mathrm{~L}$ stainless gteel capsules. 13

subtraction of the swelling strain from the total and assuming that swelling 18 independent of stress, Desıruction of a stress free capsule and also one stressed at $157 \mathrm{MPa}$ for imersion density measurements 17,18 showed no effect of applied stress on swelling for capsules Irradiated at $400^{\circ} \mathrm{C}$. This result is not universal, however, since comparison of the awelling In fuel cladding with that in unstressed samples at $530^{\circ} \mathrm{C}$ shows that the cladding, which is stressed, owells much faster. The value of the cladding otress can be measured by decermining the residusl stress after irradiation by measuring the displacesent of a slit cut in the tube. This measurenent raised another question, however, because the values messured were saaller than expected. This disagreement suggeste that swelling under this - cress may be faster, or perhaps there is a chemical change in the cladding that leads to higher awelling wich relaxes the internal stress. Th14 question was not resolved by the authors. 
One interesting coment was rade in the discussion of the restdual stress measurenents, however. Transmission electron aicroscopy showed that a swelling gradient as weasured by void size and number density did not occur. The authors correctly point out that the measuriment of voids does not necessarily zeasure swelling. Swelling ociurs in the region where the excess-interstitials precipitate. It appears that if the interstitials diffuss aiong the stross gradient, the result wil be stress enhanced swelling. If the excess interstitials wove along the stress gradient by clinb and glide of dislocations, the resulting creep relaxes the stress. These effects would be very difficult to distinguish frow each other.

As the reader can see frow above, the fmportant question relating applied stress and swelling has not been answered, Recently, Garner et al. 21 collected the avallable data and attempted to rationalize the contradictory information. Briefly, they concluded that more than one mechanisa is involved and much more work understeitding stress-affected precipitation and chemical evolution is needed before the link between stress and swelling can be resolved.

Resuits from the 316 stainless steel studies add another corplication to the problem. 16 At $400^{\circ} \mathrm{C}$ the results show very similar stress and temperature variation to th $t$ reported for $304 \mathrm{~L}$ atainless steel; but, in general, thr. deforwation rates are liss for 316 stainles8. One exception to this similarity, shown in Pig. 2, is that the 207 cold-worked and solution annealed samples shrink for the first 10 dpa of Irradiation as a result of precjpitation. Also snalysis of the swelling shows that the HTD samples begtn to swell imnediately while the $20 \%$ coldworked and solution annealed samples inilially shrink. Then, after $10 \mathrm{dpa}$ the solution annealed samples begin to swell rapidly while the cold-worked samples swell slowly to at least $40 \mathrm{dpa}$. At $550^{\circ} \mathrm{C}$ the behavior of 316 stainless, shown in Pig. 3, Is even more complicated with a nonlinear stress dependence. רd may also show a decrease in the dose required before rapid deformation begins. The analysis of the metal carbide concentration offers a strong, circuinstantial argument to explain these observations. The HTD samples have 
ORNL-DWG 81-11667

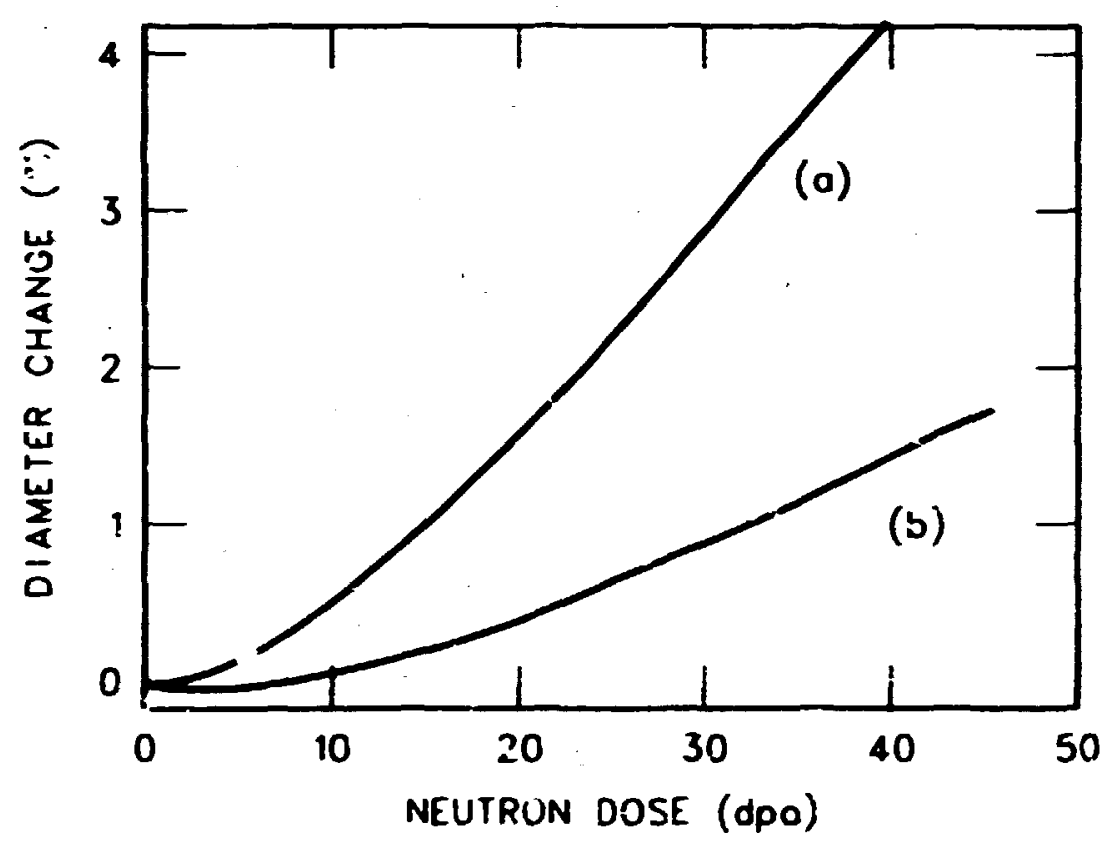

P1g. 2. The dianeter change of AISI 316 stainlest, steel pressurized tubes as a function of neutron dose 16 at $400^{\circ} \mathrm{C}$ and a hoop stress of 276 MPa. (a) Ag $\equiv d$ for 216 h at $704^{\circ} \mathrm{C}$ and (b) combination of solution annealed and $20 \mathrm{r}$ cold-worked saples.

about $15 \mathrm{gg}$ of precipitates per gran of ymple before and after irradiation. Under irradiation at $400^{\circ} \mathrm{C}$ the precipitete content of the $20 z$ cold-worked an' solution-annealed samp? es increases from nearly none to wore than $0.5 \mathrm{~m} / \mathrm{g}$ of eample, and the deformation rate increases accordingly. At $550^{\circ} \mathrm{C}$, the precipitation increases to about one iutif of that found for the FID materialo, and the deforation rate is nearly as fact. Recently, there has been significant progress in understanding the preciptcation behavior in irradiated otainless steel. 22 It is likely that the acount of precipitates not only incresse as a function of temperature and fluence but also change in crystal etructure and netal lon content. Further research way well shed some 1ight on the rechanisas for the defornation increases obse eved.

Recently, creep has been measured in ossples undergoing a gradual tempersture decrease. 23 In $20 z$ cold-woriked AISI 316 cladding, larger 


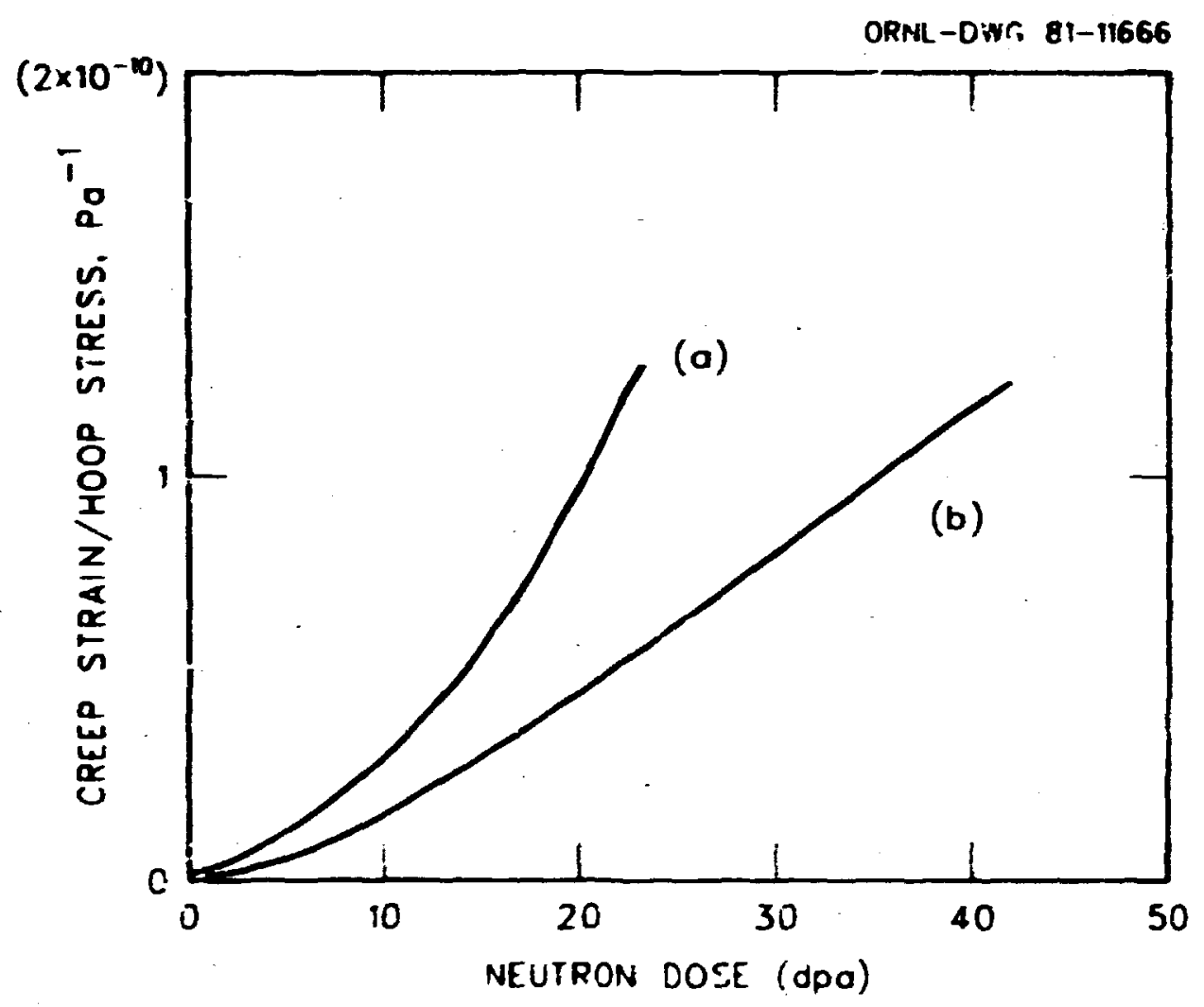

Pfg. 3. Stress nornalized creep strain as a function of neutron dose for pressurized AISI 316 stainless steel tubes 16 which had been aged for $216 \mathrm{~h}$ at $704^{\circ} \mathrm{C}$; (a) creep was measured at $550^{\circ} \mathrm{C}$ and $\sigma_{\text {hoop }}=$ $207 \mathrm{hPa}$ and (b) based on data measuted at $550^{\circ} \mathrm{C}$ wt $=\mathrm{h} \sigma_{\text {hoop }}=103 \mathrm{ha}$ and at $400^{\circ} \mathrm{C}$ with $\sigma_{\text {hoop }}=276 \mathrm{KPa}$.

creep deforations have been masured in those samples that have undergone a temperature decrease. Purther analysis of these data hive been presented along with a proposed wodel. 24 It is observed that $r$ picecipitates form during low tenperature excursions. This precipitation 1s belfeved to lead to faster afcrochentcal changes in the material. berganis et al. 25 irradiated pressurized tubes ade from two different heats of 142 cold-worked DIN 1.4981 astenitle stainless sceel. This steel is sinflar to AISI 316 and the results were also very sini1ar. Dor itrediation temeratures from $410-480^{\circ} \mathrm{C}$ and hoop streses Eros 0-237 Ma, the deformation begins slowly and then increases rapidly at about $20 \mathrm{dpa}$. The in-pile ereep rate ts proportional to stress except for the $M \mathrm{gg}^{\prime} \cdot$ it temperature, $480^{\circ} \mathrm{C}$ where a higher stress dependrze is observed. No hest-to-heat differences we found for the two heats. 
Greep deformation of pressured tubes ande from 207 cold-worked 316 stainless steel at higher temperatures has been reported by two different groups. Gilbert and Lovel1 26 extended the earlier masurements of Gilbert and Bates 27 to $720^{\circ} \mathrm{C}$. The high teaperature results are for low fluence and stresses that are high enough to cause significant thetwe: creep. Fron their data, creep behasior in the region where both theraal and Irradiation ereep xccur shows cuaplicated tenperature dependence wtu a possible decresse in creep rate when the samples are Irradiated. Hore recently, Hassilew et al. ${ }^{28}$ conducted creep tesic on 316 stainless steel saples before, during, and after irradiation at $712^{\circ} \mathrm{r}$. In all their measurewents the In-reactor creep rates were the $\mathrm{mighest}$

Pressurized tubes have been used to study irradiation creep in other alloys. These include the relatively high tenperature measurezents by Paxton et al. 29,30 of creep in a ferritic steel containing $127 \mathrm{Cr}$, three comerclal austenitlc stairiess steels, ose experimental ittaniun-rodified austenitic stainless steel, and five precipitation hardened Pe-Ni-based alloys. In eddition, recent measurements of creep in a $17 \%$ or ferritic steel at lower teaperatures have been reported by Erler et al. 31 PInally, the wethod has been used to study creep and growth of zirconiun alloys.32-34

Measurements of creep under the case conditions for cen differeat alloys, described above, gives a very powerful method to comare the behavior of different arerisls. Paxton et al. 29,30 measured the creep of these ten alloys in a cutal of 17 etallurgical condition, under four stresses, and at two cemperatures, nominally 540 and $60^{\circ} \%$. The five precipitation hardening alloje, all of wich depend on $r^{\prime}$

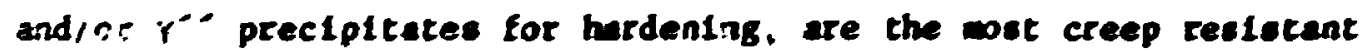
and show a llneer stress dependence although the exact weaning of the syulis are subject to Interpretation. swelling contributes to the diactesl straln and is wasured to be function of atress in one of the ausenfitc ater!als, colu-workat IISI 316 at $540^{\circ} \mathrm{C}$. When this swelling is resoved from the tutal strain, the resulting creep curve iz wh the linear ln stresa. Nen tor another atertal, AIsI 330. the creep rate is the anse boch in and out of reactor at $605^{\circ} \mathrm{C}$. It is 
likely, therefore, that wuch of the nonlinear stress dependence is a result of therand creep.

One last complication is observed for two of the precipltatior. hardening raterlals, $M-813$ and PE-16. An inverse temptrature dependence 18 measured for creep. This decrease in creep rate for an Increase In temperature is accompanied by 2 very strong tecrease in swelling which offers further support for the direct relationship between creep and swelling.

The creep and owelling of ferritic materials at lower temperatures, $400-550^{\circ} \mathrm{C}$, was reported by Erler et al. 31 The results are very simple to report in that vold swelling is confined to the o-phase particles forned durfing some heat treatments. The creep rate that accompanied the very low arelling rate is correspondingly low. Very few weasurements of creep greater than 0.22 were measured for irradiat son out to $150 \mathrm{dpa}$.

Pressurized tabes of another form have been used to study creep in zilconiun alloys. The tubes used for the study were the large pressurz tubes used in \& number of heavy water reactors. The ends of the cubes were constraincd; therefore, the stress state was wre conplicated than a simple pressurized tuhe. zircontum is an anisotropic materkal, and the obset jed str.ifn fo a combination of anisotrople growl.l and creep. The deformation mechanisins are coaplicated and depend on mallurgical variables that are difflult to concrol. Rolstad ${ }^{34}$ has recently made a comparative evaluation of sme experimental daty using ten different creep cortelations, and the predicted strain using these equations varted by an order of ragnitude. This dispartty is a good 1llustration of the difficulty in understanding irradiation creep lo these anisotropic materials.

As an example of a method so Improve understanding of creep and growth in Irradiated 7.1rcaloy tubes, we would like to mention the movel developed by Holt. 32 He based the model on a quantitative cortelation describing both the clongation and diametral strain of zircaloy pressure tubes which were manufactured in elght different procedures and Irradiated in four power reactors. The results of the cortelation show that the growth rate is approxinately, pruportional to 
dislocation densit-, Increrses in the direction of elongating grains, and also increases in the direction that has a decreasing number of besal plane norasis. The creep rate, on the other hand, is insensitive to dislocation density, but is related instead to the texture of the tube. The model successfully predicts the dianetral and longitudinal strain rates for tubes expertencing end loads during operation. In a later peper, ${ }^{33}$ the model is used to define ideal textures and grain sizes for reactor pressure tubes.

\section{IRRADiat10N CREE.P UADER COASTANT APPLIED LOAD}

Although pressurized tubes have been useful in measuring frradiation creep data, expericents which have a simpler applied stress are of ten easier to interpret and compare. In addition, the study of initial strain iransients or translents in load or temperature requires a fully instrsmented creep machine wich can record data continuously. The first of these requirements was achieved early in the study of Irradiation creep.

Mosedale and coworkers ${ }^{35-37}$ used a technique of applying a constant load to helical spring samples immersed in Iquid godium. The strain was deterni.ed by measuring $X$-radiographs taken in a hot cell aftar Irradiation. This method has the advantages that the applied loads do not change during the test and the epplied stress is nearly pure shear. It har the disacvantages, however, that the strain can be determined only at intervals when the capsules are rewoved from the reactor. In their earlier results 35 irtadiation induced creep was measured at $300^{\circ} \mathrm{C}$ in a variety cf materials including Mimonic PEI6, Nimonic $80 \mathrm{~A}, 316$ stainless steel, wlybdenum, and nickel. More recent results 36,37 are focused on mater 1 als for fast reactor cures, nemely five different austenitic stainless steel uljoys. The results for all the alloys are similar with linear stress and dose dependence. The tenperature dependence is wak and appears to depend on the material. In some cases the creep rate increases wth increasing tewperature and in others it decreases. There appears to be strong evidence to support a damage rate dependence. The strain per dpa tends 
to decrease with increasing danage rate. Two curves have been replotted ic Fig. 4. The norwalized creep strain/dpa shows a linear dependence on the inverse squart root of the damage rate. This dependence 18 expected from theory 38 when defect recombination is the doninant rode of loss. Although nicrostructural evidence is not avallable, this condicion is likely. The decreasing creep rate with increased danage rate my lead to lower creep rate in o'lsed systens because these systens wil have higher dqmag: rates for the saxe average danage. No mention of sweiling was made and although the total damage was as high as $15.5 \mathrm{dpa}$ for 316 gtainless fte.sl and up to $36 \mathrm{dpa}$ for some of the other allcrs, nu Indication of a rapld increase in creep rate ras observed. The creep rates were nearly constant from 1 dpa until the tests were terainated. An sttent to compare the results with cther data from pressinized tubes and tensile creep tests cended to uncover the somplex aspects of irradiation creep behavior but "...no simple generalization..." appears to be possible at the monent. 7

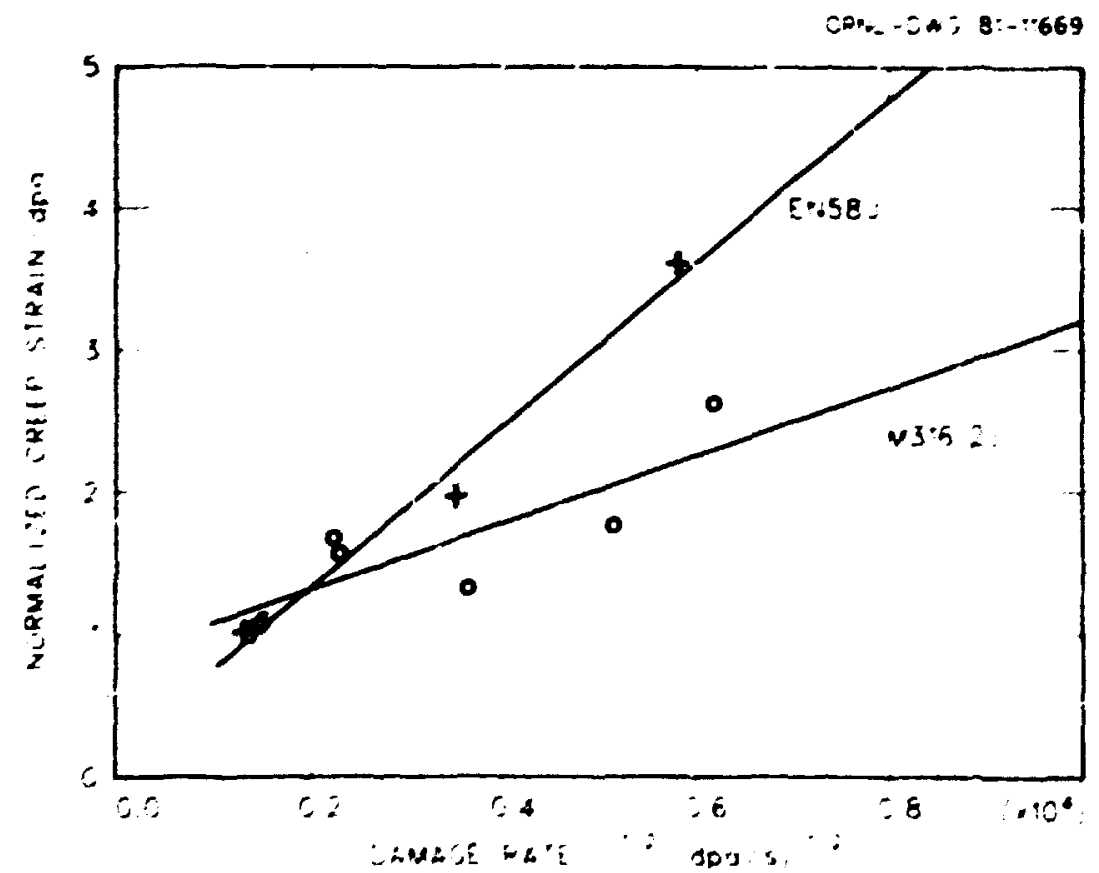

P1g. 4. The normilized creep otrain per dpa plotted againat the square rost of the danage rate for two austentic stainless strels. The date are replotted from Ref. 37. 
The wethod of loading helical springs has also bzen used to study Irrucjaction creep of nickel alloys ${ }^{39}$ for temperatures fron 270 to $300^{\circ} \mathrm{C}$. Three types of nickel alloys were studied: solid solution strengthened with rolybienum, precipitation hardened with alunimu, and dispersion strengthened with the additions of $\mathrm{Al}_{2} \mathrm{O}_{3}$. Sose of the result: are shown in Fig. 5. In seral, alloys which showed the grearest reduction in therwal creap also showed the greatest reduction 1: Irzadiation creep. A strong dose rate effect was encountered which rade direct compariscas difficult. At a low dasage rate $\left(=2.5 \times 10^{-8}\right.$ d)a; i) the alloys containing aluninum and wolybdenun crept at about ithe same rate ais pure nickel while at a higher danage rate $\left(\neq 10^{-7}\right.$ $(j a / 5)$ the alloys crept ibout ten times slower than pure niciel. A recent report 40 of creep rates in modified AISI 316 also supports ztrong alloying effects or the creep rate. In particular, edditions of silicon and mlybdenum decrease the creep rate. In general, the sac elewents that reduce owelling also reduce creep.

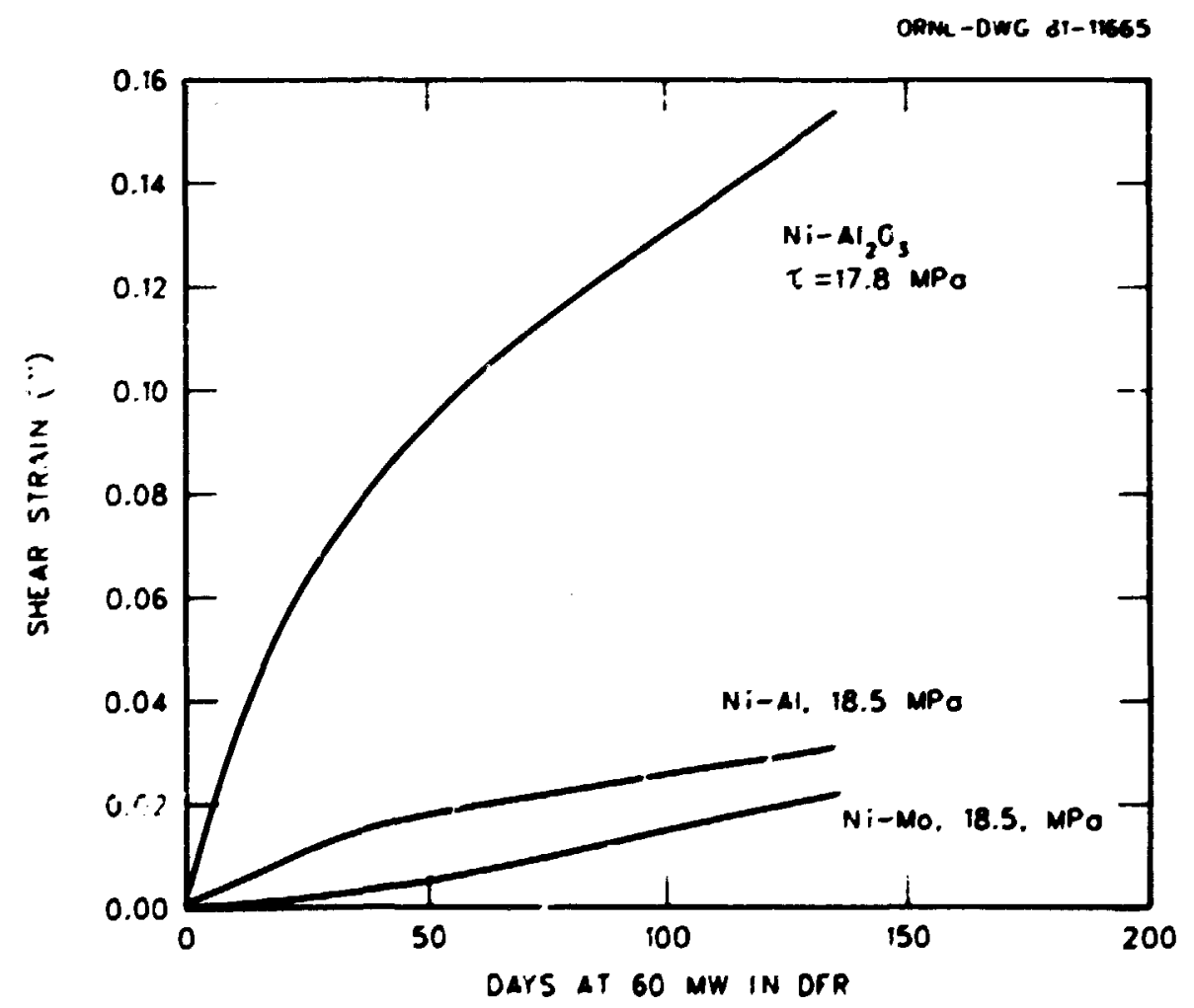

P1g. 5. The shear creep itrain as a function of dose for three differeit alloys of nickel (replotted from Ref. 39). 
Up to this point all the experimental techniques discussed Involve measurement of the creep strain at Intervals when the samples are out of reactor. In order to study strain transients and creep at low fluence, it is necessary to measure str.un cont nomusly. There are data reported from at least five different fully instrumented creep test asseablies. Although the muber of reported experinents is small and the result; are inconclusive, shese experiments will now be discussed.

In 1972, Gilbert et al. 41 reported a partially successful experiment to measure in-resctor creep continuously. A specimen of 207 coldworked 316 stalnless steel was crept undér uniaxial stress of $138 \mathrm{MPa}$ at $454^{\circ} \mathrm{C}$. The measurements teminated prematurely when the machine falled. The measured steady-stace creep rate, $1.2 \times 10^{-10} \mathrm{~s}^{-1}$ is higher than valises masured using pressurtzed tubes but is about 302 lower than the values reported below for type 321 stainless steel.

Two spectwens of 207 cold-worked Er58B (type 321) stainless steel were Licradiated in a tension creep sachine in JFR. 36 The first sample was irradiated at $500^{\circ} \mathrm{C}$ for $960 \mathrm{~h}$ at $93.1 \mathrm{MPa}$ followed by $275 \mathrm{~h}$ at $41.0 \mathrm{MPa}$. The observed steady state creep rates were $1.6 \times 10^{-10}$ and $5.8 \times 10^{-11} 8^{-1}$, respectively. The second specimen was irradiated at $500^{\circ} \mathrm{C}$ unstressed unt 11 a dose of 11.1 dpa and was then creep tested at 500,450 , and $400^{\circ} \mathrm{C}$ at $93.1 \mathrm{MPa}$ arj also at $400^{\circ} \mathrm{C}$ at 13.8 and 48 MPa. Under irradiation at these temperatures this steel undergoes sowe swelling and also shows sone phase instability which complicates the interpretation of the creep data. Several observations are posefble, however. Strain transients which lasted from 1 to 2 dpa were seen when the stress was increased. These transients did not appear when the stress was reduced. The pre-1rradiation of the second sample did not seen to be important in influencing creep rate; the average measurad creep rate at $93.1 \mathrm{MPa}$ was nearly the same in the two samples. The creep rate increased about a factor of 4 as the temperature decreased from 450 to $400^{\circ} \mathrm{C}$. This trend was not expected to continue since the creep rate was higher at these ter. peratures than that measured on hellcai springs at $280^{\circ} \mathrm{C}$. No satisfactory explanation was offered for this negative temperature dependence. 
Based on publisbed results, perhaps the not successful design for in in-reactor creep anchine is that based on the ressant carity strain sensurenent developed at Grenoble. Creep achlnes have been built for both the Rapaodie and 122 reactors. Dupouy et al. 42 reported results from three experiments ade in rapsodie. All three spectmens were 316 stainless steel - the first was solution annealed and the other two were $20 \mathrm{z}$ coid worked. The equipment falled during the first experinent and the data were incomplete. The other two experiments were cartied out at $450^{\circ} \mathrm{C}$ end at a high applieri stress of $400 \mathrm{MPa}$. After little if any transient creop, the meapured creep rates were 1.7 and $1.4 \times 10^{-9} \mathrm{~s}^{-1}$, respectiveiy. The second saple was Irradiated to 36 dpa and the creep rate remained linear with dose throughout the experiment.

Several successful experiments using a creep machine in the 122 res-tor have been repcrted. 43 Three opecinens of DIN 1.4981 stainless steel ( $16 \mathrm{Cr}, 16 \mathrm{N1}, \mathrm{Nb}$ ) were irradiated at stresses of from 100 to $200 \mathrm{MPa}$. The Irradiation remperature for the three samples was Initially 420,450 , and $500^{\circ} \mathrm{C}$; however, a heater fallure in the second experiment caused the temperature to decrease to $350^{\circ} \mathrm{C}$. DurIng this temperature decrease, which lasted about $2000 \mathrm{~h}$, no change In the creep rate was masured. The observed temperature dependence is not strong with the waximum creep rate at $420^{\circ} \mathrm{C}$ and the minimum at $450^{\circ} \mathrm{C}$. The stress dependence based on stress-change neasurements Is IInear, but an unusual observation was made. After creaping to a dose of about $12 \mathrm{dpa}$, the $420^{\circ} \mathrm{C}$ specinen was irrsdiated at zero stress for some time and then reloaded to $100 \mathrm{MPa}$. No deformation was observed for two reactor cycles and then the creep began at a rate double that measured previously at $100 \mathrm{dpa}$. ije belleve that it is possible that rapid swelling began at that dose and the measured enhanced creep rate reflects swelling-driven creep. No density measurements have been made.

The creep behavior of ferritic steel DIN $1.6770(2.2 \mathrm{Cr}, 1.01 \mathrm{Mo}$, $0.8 \mathrm{NH}$ ) has also been measured using the resonant cavity apparatus. 44 .. Irradiations out to a fluence of $4.5 \mathrm{dpa}$ and stress to $200 \mathrm{MPa}$ at $400^{\circ} \mathrm{C}$, the creep rate was 1 ess than $2.2 \times 10^{-11} \mathrm{~B}^{-1}$. At $500^{\circ} \mathrm{C}$ 
and 100 re the strain rate increases with time (11ke tertiary creep) and is about five times as fast as in a typical austenitic stainless steel. Coutinution of the $400^{\circ} \mathrm{C}$ saple at $500^{\circ} \mathrm{C}$ reproduced the sase result. The $500^{\circ} \mathrm{C}$ result is about ten times as fast as theral creep In the sane material, but has the same general behavior.

Another successful creep machine has been used to study in-reactor creep of zirconiun alloys. No results publisbed by hacisen and Pidleris will be sevieved. Pirst, in an early report 45 the creep of Zircaloy-2 was neasured $1 \mathrm{n}$ and out of reactor at $335 \mathrm{~K}$ and $25 \mathrm{Ha}$. After an initial transient of about $50 \mathrm{~h}$, ateady state creep rate of $5.6 \times 10^{-10} \mathrm{~s}^{-1}$ was mesured. Then, when the reactor was shut down, a very large inttial increase in the creep rate was observed. This increase was oniy a 1 to 2 h transient, however, during which the creep rate dropped to an insignificant value. The authors offered convincing arguwents to support the Idea that the increase in creep rate occurs through a climb-glide process driven by the excess vacancies in the naterlal. This explanation was discarded later, however, when this same phenomenon was observed in ocher experiments. 46 Continued Irradiation showed that the "transient strain" was primarily due to theraal expansion and contraction of the creep machine. One test on a ztrcontun single crystal was continued for $5800 \mathrm{~h}$ at $300^{\circ} \mathrm{C}$ and $25 \mathrm{MPa}$ and the fins.. obser:ed strain rate was $3.9 \times 10^{-10}: !$ This conpared to less than $1.4 \times 10^{-10} \mathrm{~s}^{-1}$ during reactor shutdown periods. A second crystal was irradiated at a 707 higher flux at $5.8 \mathrm{MPa}$ and $300^{\circ} \mathrm{C}$. Then, juring a long reactor shutdown, the stress was ralsed to $25 \mathrm{MPa}$. The creep rate was Initially about half of the steady state value of the first crystal but slowly increased to a value 2.4 tines the value of the other crystal. The aicrostructure of the first specinen was studied, and the visthle dasage was seen to be almost entirely sall loops with a denstey of $4.5 \times 10^{20} \mathrm{~m}^{-3}$ and an average size of $13.5 \mathrm{~nm}$. A low magnification alcrograph revealed owathes through the loops probsbly cleared by glide of network dislocations. He belleve that the majority of the observed strain occurs fron the glide of these dislocations which removes the loops. A nodel was suggested for this flux-enhanced swath formation. 


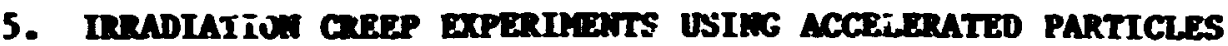

The final class of experiments desigmed to study irradiation-induced creep phenomena are those which use beans of accelerated particles to cause the irradiation danage. During the last ten years there have been a variety of experimental efforts utilizing many ditferent particles Including electrons, neutrous, protrons, deuterons, and alphs particles. In all casex, thin wetal amles are loaded in complex devices on the target end of a large accelerator. For reasoanble Irradiacion times the cotal Irradiation dose 18 anall, and so great care wust be taken to mainize thermal transients both in the opecinen and the achine. Sall temperature changes result in large strain errors. In addition, the particle bean produce radically different prinary danage energy spectra which makes comparisoas with reactor data difficult. The major advantage of these system is that the experinental variables - stress, temperatures, and fluence - are known more precisely, and analysis of the data produces important inforation sbout the underlying physical mechanisms.

There have been only a few electron and neutron experinents so they will be briefiy considered first. The range of elect. sar with energy of the order of $1 \mathrm{MeV}$ in metals Is short so that the eample thickness is linted tc a few acrons. This severe restriction elininates the use of electron beans from producing bulk waterial creep data. On the other hand, the very thin foll is an advantage, In that, by using a high woltage transmission electron aicroscope it is possible to observe the changes in the internal stucture during Irradiation. Buckley and Manthorpe 47 Irradiated aluninum-silicon alloys In an FVEA and were able to calculate the local stress on network dislocations by weasuring dislocation bowing. The outcone of these mesurements is that during an hour of irradiation the local stress on Individusl dislocations changed by orders of agnitude and even sign. The withors write, "one affects all and all affects one." This somewhat obvious conclusion has been almost completely ignored in theoretical models for irradiation creep. 
Another in-situ irradiation creep experinent under HVEM irradiation has been reporter. on annealed 316 stainless steel ${ }^{48}$ along with some cbservations of theral creep. Theral creep is characterized by heterogeneous planar glide of networt dislocations leading to rapid hardening and decreesing creep rates. Irradiation cresp shows mucleation, grouth, and unfaulting of Frank lwops. These unfaulted loops glide to foin the metwork. Applied stress leads to preferential mucleation and unfaulting of those loops whose Burgers vectors ake the anpllest angle to the tensile stress. This work shows a definjte difference in wechasisis between thermal and irradiacion creep.

studying creep with electrons and light lons offer a partial solution to the problew of obtaining Information under bet ier kawn experimental conditions, but in reactors almost all the damge occurs through interactions of neutrons. Because of the availability of neutrons from fission reactors, the darage from fission neutronc has been studied. For fusion resctors, which produce a high iraction of $14 \mathrm{HeV}$ neutrons, nothing is known. Two high etwergy neutron sources have been used to study differences that high energy neutrons aght ake. One of these sources, the Be(d,n) source at the University of Calfiornia at Davis has been used to study Irradiation creep. 49 A sample of annealed niobium war Irradiated at $600^{\circ} \mathrm{C}$ under a stress of $76 \mathrm{mPa}$ after steady state thermal creep was established at $1.4 \times 10^{-6} \mathrm{~s}^{-1}$. Then, a series of 12 short beam-on, beam-off cycles were conducted. When the bean was turned on the creep rate imediately increased about 302. Then the creep rate decayed Auring the next 6000 to a value less than 1/10 of the cheraal value. When the bera was turned off the creep rate decreased Imediately and then slowly returned to near the thermal value during the next 6000 s. The authors believed that the short transients were due to first an increase and then a decrease on the interatitial concentration while the long transients resulted rrom vacancy clusters.

The early experiments using lon beans uncovered the difficulty encountered in mintaining very precise ceaperature control, but they also demonstraced the basic usefulness of the approsch. Buckley and Manthorpe 47 irradiated pure copper with $4 \mathrm{MeV}$ protons at $2 \times 10^{-6} \mathrm{o}^{-1}$. $17^{\circ} \mathrm{C}$, and with applied stresses of 10 und SO MPa. The experinent 
showed considerable enhancenent in the creep rate bit quantitative values were not possible. Harkness et al. 50 reported results on three stainless steel sapies Irradiated with $22.4 \mathrm{HeV}$ deuterons. The creep rate of a saple of solution annealed 304 stainless steel, Irrachated at $416^{\circ} \mathrm{C}$ under stress of $414 \mathrm{HPa}$, was found to be about nine times higher than the thermal creep rate of $4.2 \times 10^{-9} \mathrm{~s}^{-1}$. The observed weak temperature dependence reflected an activation energy of $34 \mathrm{~kJ} \mathrm{col}^{-1} \cdot \mathrm{C}^{-1}$. This sane steel pre-irradiated in EBR-II to a fluence of $5 \times 10^{25} \mathrm{n} / \mathrm{m}^{2}$ showed a factor of 15 decrease in the protron induced irrediation creep. After adjustnent for different irradiation temperatures and stress, the masured value showed good agreenent with In-reactor creep rates measured using pressurized tubes. Creep of $20 \mathrm{z}$ cold-worked 316 was also measured at $505^{\circ} \mathrm{C}$. A $1-2$ power stress dependence was found, which compares to a thermal creep stress dependence of about 9.

Irradiation creep of high purity nickel has been investigated for several years using both deuteron and alpha particle beans. In 1976, Hendricks et al. 51 reported a creep rate of $7.5 \times 10^{-9} 8^{-1}$ in nickel Irradiated with $22 \mathrm{HeV}$ deuterons at $224^{\circ} \mathrm{C}$. The creep rate was several orders of agnituda higher than that expected for thermal creep. Other measurements were made with this same creep machine 52 using both $22 \mathrm{MeV}$ deuterons and alco $70 \mathrm{HeV}$ alpha particles. If the danage functions are correct, about $20 \%$ fewer defects contributed to irradiation creep from alpha particles than for deuterons, (1.e., deuterons were about 257 wre effective in causing irradiation creep). In this work the inttial transient appeared to saturate after $12 \mathrm{~h}$ of irradiation. Stress change experiments with wot stresses above $200 \mathrm{MPa}$ give an applied stress exponent of from 1.67 to 2.00 . The results are consistent, however, with a linear stress dependence for stresses less than $200 \mathrm{MPa}$. Mirrostructural observations showed an Increased loop size with increased stress. This work was continued 53 with emphasis on the microstructure during the initial transient. After $8 \mathrm{~h}$ of Irradiation the initial dislocation density of $2 \times 10^{15} \mathrm{~m}^{-2}$ decreased to $3.2 \times 10^{14} \mathrm{~m}^{-2}$. During this same perfod the defect cluster density Increased frov lese then $1 \times 10^{19} \mathrm{~m}^{-3}$ to $1.4 \times 10^{22} \mathrm{~m}^{-3}$, and the average size of the clusters changed from $2.9 \mathrm{~nm}$ to $4.3 \mathrm{~nm}$. The creep 
rate divided by the flux decreased from 4.3 to $0.05 \mathrm{dpa}^{-1}$. The study of nickel continued on another accelerator using $17 \mathrm{MeV}$ deuterons. 54 For a specimen of nickel loaded to $215 \mathrm{MPa}$ at $220^{\circ} \mathrm{C}$, the steady state Irradiation creep rate was found to be $2.6 \times 10^{-8} \mathrm{~s}^{-1}$ for a damage rate of $5.4 \times 10^{-7} \mathrm{dpa} / \mathrm{s}$.

Before the test, the thermal creep rate was about $70 \mathrm{z}$ of this value; but after $a$ total dose of $0.055 \mathrm{dpa}$, the thermal creep rate was reduced to $10 \mathrm{z}$ of irradiation creep values. The sane machine was used to evaluate the stress and temperature dependence of irradiation creep In pure, cold-worked nickel. 55 For a stress range of 205 to $250 \mathrm{HPa}$ the steady state rreep stress exponent was 2.5. An increase of $40^{\circ} \mathrm{C}$ elevated the creep rate by a factor of 1.44 which was less than expected. In all these studies the creep rates were greater than $2.0 \times 10^{-9} 8^{-1}$ and the stresses were higher than $200 \mathrm{MPa}$. Most previously discussed results, showing linear stress dependence, were measured at lower applied stress.

McElroy and co-workers $36,56,57$ have reported creep measurements on pure nickel and 321 stainless steel using thin samples ( $=25$ um) and irradiating with $4 \mathrm{MeV}$ protons. In the initial report, 56 irradiation and thermal creep of pure nickel was measured for temperatures frow $400-600^{\circ} \mathrm{C}$ and stresses from 20-200 MPa. Thermal creep agrees with that reported for bulk specimens with an activation energy of $2.8 \mathrm{eV}$. Under irradiation the thermal creep rate decreases while the Irradiation creep rate continues at a rate in excess of the thermal rate. Below $125 \mathrm{MPa}$, Irradiation creep shows a linear stress dependence. Electron microscopy reveals more dislocation line segments for otressed specimens while unstressed specimens show more loops. The work was continued with emphasis on creep in comercial 321 stainless.57 The measured irradiation creep rate on $60 \%$ cold-worked samples shows a linear siress dependence for stresses less chan 150 MPa, a logarithmic time dependence, and a o.uall temperature dependence below $520^{\circ} \mathrm{C}(u>0.9 \mathrm{eV})$. Above this cemperature the temperature Hependenc = 18 atout the same as self diffusion. Electron microscopy after $0.22 \mathrm{dpa}$ at $150 \mathrm{MPa}$ revealed a very htgh dis?ocation density $\left(10^{15} \mathrm{~m}^{-2}\right)$ and showed very few stgns of trradiation damage. This 
nicrostructure is in contrast to that seen for a solution annealed sample which had alnost no network dislocations ard an unfaulted loop density of $2 \times 10^{22} \mathrm{~m}^{-3}$ with an average diameter of $8.5 \mathrm{~m}$. Since the total dose that can e achieved in these devices is low, an attent was made to pre-irradiate some samples under stress and then measure the irradiation creep. 36 For a pre-irradiation to $7.1 \mathrm{pa}$ at $440^{\circ} \mathrm{C}$ under a stress of $50 \mathrm{kPa}$, the subsequent creep rates were nearly the sane as those measured before the pre-irradiation. Only the swelling strain was subtrac:ed. No stress effect on swelling was seen.

Recently several investigators have published results on irradiation creep in AISI 316 stainless steels. Blanchard et al.58 irradiated 50-po-thick specinens with $29.4 \mathrm{KeV}$ alpha particles at temperatures from 300 to $450^{\circ} \mathrm{C}$. A total dose of 1 dpa was achieved with a danage rate of $10^{-5} \mathrm{dpa} 8^{-1}$. One significant new result is that addition of 0.25 wt $Z$ Ti to this steel decreases the reep rate by a factor of from 2-3.

In another approach Jung et al,59,60 have re,orted creep results on 50-thick foils of 207 coldworked AISI 316 stainless steels bowbarded with $10 \mathrm{MeV}$ deuterons and $7 \mathrm{MeV}$ protons. Por temperatures between 300 and $400^{\circ} \mathrm{C}$ the irradiation creep increases about the same fraction as that seen from neutron data. The stress dependence is quadratic above $250 \mathrm{MPa}$. Samples of a very low impurity content heat of this steel creep wch faster than the comwercial heat. Very careful analysis of the damage functions for the deuterons and protons sirows no difference in creep behavior between the two particles. In a separbte experiment Refley et al. 61 report creep rates in agreement with these results using a beam of $60 \mathrm{MeV}$ alpha particles. These alpha particles produce primary recsils having 0.1 to $1.0 \mathrm{MeV}$; and therefore, the dasage spectrun should be wore ilke that found in fast reactors. The agreement between these last zesults using beams of three different particles 16 in contrast to the difference between deuterona and alpha-particles rentioned previoisly. 52 all the reported ton irradiation creep rates are from 2 to in times higher than that found for neutron Irradiation. It appears that questions concerning defect production and cascade structures still do not have 
completely satisfactory answers. Also, very recent measurements ${ }^{62}$ of swelling in deuteron bonbarded high purity stainless steel have shown a decrease in incubation dose with applied stress. It is likely that an accompanying change in creep ill occur.

Torsion creep under 21 MeV deuteron irradiation of solution annealed and aged $\left(6 \mathrm{~h}\right.$ at $\left.800^{\circ} \mathrm{C}\right)$ AISI 316 stainless steel has been neasured at $400^{\circ} \mathrm{C}$ at a maximun stress of $110 \mathrm{MPa} .63$ The stress is lower than the previous.; reported creep experiments on this steel and the results are in sharp contrast. For the first $0.15 \mathrm{dpa}$, the observed creep rate is negative, (f.e., the creep strain opposed the applied stress). The explanation for this phenomenon is based on an increase in shear wodulus for the material as a function of irradiation resulting from the precipitation of $\mathrm{N}_{-2} \mathrm{Si}$ particles which decreases the matrix concentration of these elements. No microstructural information was presented. In the torsion experiment, an increase in shear modulus w.:11 result in a negative strain to mafntain a constant applied stress.

Figure 6 is a plot of these results for cold-worked 316 stainless steel along with some results using protons and deuterons. The solid sywbols refer to measurements made on specimens which had been precrept. Note that no significant difference is observed.

In another set of experiments using this same torsionall creep apparatus, 64 pure nickel and $\mathrm{Ni}-4$ at. 7 si were studied at $350^{\circ} \mathrm{C}$. In all the experiments pre- and postirradiation creep rates were measured, and significant irradiation-induced hardening was seen. The torsionsl machine allows measurements down to a creep rate of $2 \times 10^{-10} \mathrm{~s}^{-1}$ which is lower than the rates reported using other machines. This capability allows creep studies at low stresses, 23 to $110 \mathrm{MPa}$, which makes the data more comparable to tinat measured in-resctor. In light of this, a linear stress dependence was measured for stresses less than $70 \mathrm{MPa}$. Above this stress the creep rate incresses faster. The creep rate was linear in dose and the observed radiation hardening saturates for doses greater than 0.01 dpa. The silicon alloy shows more hardening and microstructural observacions show higher deilgity of sall prank loops decorated with $\mathrm{N}_{3} \mathrm{SI}$. 


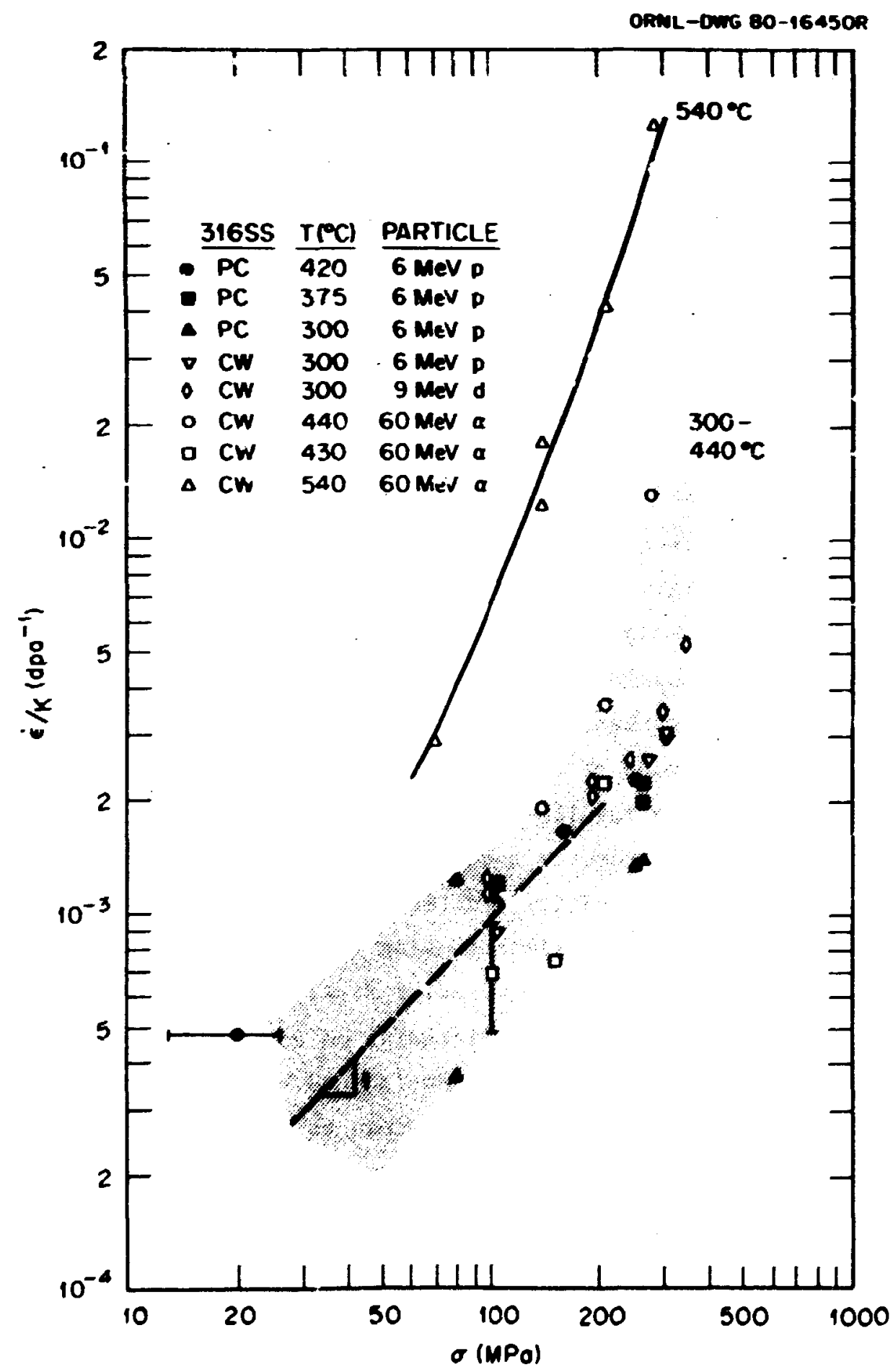

P1g. 6. A sumary plot of irradiation creep of 316 stainless steel under charged particle irradiation. The olid points designate samples that were pre-crept (PC) thermally before irradiation. 


\section{SUIAARY OF IMPORTANT RESULTS AND SUGGESTED AREAS FOR RESEARCH}

Many of the sain features of Irradiation creep behav'.or had been reported prior to 1977 . Such properties as strain increasing with fluence, ifnear with applied struss, and only weakly dependent on temperature had been reported. However, since 1977 there have been several surprising result.s, and these have been sumarized in this report.

During this tiwe there have been several reports relating creep and swelling. Data have been reported showing that large increases in swelling are accompanied by large increases in creep. In addition, those alloying additions that depress swelling also thad to reduce the creep. The connections becowe even more complicated with the observation that swelling depends on the applied stress - at least in some alloys at high temperaturee. Finally, there is a role played by Irradiation-induced or -enhanced precipitation. Each of these phenomena have been observed and reported recently along with the connection to irradiation creep, but the wechanisms connecting them were not understood. Ongoing work fs addressing some of these questiors. 65

The effect of temperature on Irradiation creep has also been explored and some surprising observations have been made. Formerly, irradiation creep had been thought to be nearly independent of temperature, and there have been a large number of observations to support this weak dependence. The temperature range for these measurements was limited, however, and noie recent measurements at lower temperatures have shown an inverse temperature dependence. The creep rate increases considerably as the temperature decreases. Further, it appears that temperature decreases during creep can result in increased strain. Many additional creep tests are needed, especially those using the same measurement techniques, over the entire temperature range. Accismpanying microstructural observations are also needed to determine the mechanisms establinhing the complicated temperatire dependence. It appears that radiation-induced nonequilibrium precipitation plays a role. 
The stress dependence of Irradiation creep appears to increase at high stresses and temperatures. It appears that this increase results from the same processes leading to theraal creep, but it occurs in the radiation damage structure. The resulting creep rate is faster than therwal creep of a thermal creep structure. Also some nonlinear stress dependence appears to be related to stress dependent swelling, and this is not understood.

Another sonewhat surprising result is the apparent difference in the fluence dependence for samples stressed in torsion and for pressurized tubes which ate biaxially stressed. A linear creep rate as a function of fluence has been seen in dead-weight loadeci springs for fluences fron 1 to 40 dpa, whereas the pressurized tubes show an increasing creep rate for the first several dpa. Also, sone measurements using charged particle creep apparatus show a dependence of Inculation dose on applied atress. Understanding these observations would aid in the development of a more realistic creep equation.

In conclusion, the observations reported during the last few years continue to challenge our understanding of the physical processes governing irradiation creep behavior. It continues to be necessary to couple measurements of creep with those of swelling and also microstructural observations. This last involves not only the dislocation structure that leads to creep but also the alloy segregation, precipitate formation, and cavity behavior. Each of these processes plays an Important role in controlling the flow of defects that determines radiation damage processes.

\section{ACKNOWLEDGIENTS}

I would like to thank $P$. W. Wiffen for his help in obtaining - veral of the references cited and $L$. $K$. Mansur for helpful discussions during this work. Also, I would like to thank R. L. Klueh and $L$. $K$. Mansur for reviewing the manuscript. 


\section{REYEREWCES}

1. R. V. Hesketh, Trradiation Creep,- pp. 221-231 in Proc. BRES Conf. Imadiation Enmittlement and Creep in Puel Madding and Core Lomponents, London, Noverber 1972.

2. John Citcus, Creep, viscoelasticitys ond Creep Practure in Solids, John Hiley Sons, New York, 1975, Pp. 203-273.

3. Jerry L. Straalsund, "Irradiation Creep in Breeder Reactor,PP. 1-91 in Inter. Conf: Rad. Bff. in Breeder Reactor Structuml Mter., Seottedale, Amizona, Jume 1.9, 1977), (ed. by M. L. Bleiberg and J. W. Bennett), AIMR, New York, 1977.

4. D. R. Harries, "Irradiation Creep in Non-Fissile Metals and Alloys," J. Hucl. Mater. 65 (1977) 157-173.

5. F. Povolo, The Determination of Creep Constants fron StressRelaxation Measurewants in Bending and Torsion," $J$. Muci. Mater. 68 (1977) 308-314.

6. F. Povolo and E. H. Toscane, "On Stress-Relaxation in Bending: For Example Results Applied to Zircaloy $4, " \pi$, Nucl. Mater. 74 (1978) 76-83.

7. F. Povolo and M. Higa, "Stress-Relaxation in Bending, at $673 \mathrm{~K}$, of Stress-Relieved and Cold-Worked Zircaloy-4,"J. Nucl. Mater. 91 (1980) 1\&9-199.

8. T. A. Kenfield, H. J. Busboom, and H. K. Appleby, "In-Reactor Stress Relaxation in Bending of $20 z$ Cold-Worked 316 Stainless Steel," J. Nicl. Mater. 66 (1977) 238-243.

9. R. Taylor and A. Jeffs, "The Effect of Irradiation on Stress Relaxation in Nimonic BOA," $T$. Mucl. Mater. 19 (1966) 142-148.

10. L. C. Walters and W. E. Ruther, "In-Reactor Stress Relaxation of Iaconel X750 Springs," J. Nicl. Mater. 68 (1977) 324-333.

11. E. R. Gilbert, J. L. Straalsund, and G. L. Hire, "Irradiation Creep Data in Supiore of LMFBR Core Design," $\%$. Nucl. Mater. 65 (1977) 266-278.

12. B. A. Chin and J. L. Straalsund, "The Effect of a Temperature Change on the In-Reactor Creep of $20 \%$ Cold Horked AISI 316 Stainless Steel," J. Mucl. Mater. 74 (1978) 260-266.

13. G. L. Wire and J. L. Straalsuad, "Irradiation Induced StressRelaxation of Previously Irradiated 304 Stainless Steel in a Past Plux Environment," $r$. Nucl. Nater. 64 (197i) 254-264. 
14. B. A. Chin, J. L. Straalsund, and G. L. Wire, Irradiation Creep of Previously Irradiated 304 Stainless Steel in a Fast Flux Environnent," J. Mrel. Mater. 75 (1978) $274-281$.

15. A. R. Causey, G.J.C. Carpenter, end S. R. Mackwen, -In-Reactor Stress Relaxation of Selected Hetals and Alloys at Low Temeracures, $"$ d. Tuct. Mater. 90 (1980) 216-223.

16. L. C. Malters, G. L. MeVay, and G. D. Hudman, "Irradiation-Induced Creep in 316 and 304L Stainless Steels,- pp. 277-294 in Irtes. Conf: Fund. Fff. in Areeder Renctor Structurat Mater., Scotterlaie, A mizona, Jume 19, 1977 (ed. by M. L. Bleiberg and J. W. Bennete), AIHE, New York, 1977.

17. L. C. Malters and J. E. Flinn, "Swelling Results fron HeliumPressurized 304L Stainless Steel Tubes," J. Wucl. Mater. 52 (1974) 112-114.

18. J. E. Flinn, G. L. McVay, and L. C. Halters, "in-Reactor Deforwation of Solution Annealed Type 304L Stainless Steel," . wucl. Mter. 65 (1977) 210-223.

19. G. L. Hofnan, L. C. Halters, and G. L. McVas, The Effect of Phase Instability of Stainless Steel on the Cladding Deformation Profiles of LAPBR Fuel Elements," T. Nucl. Mater. 67 (1977) 289-294.

20. G. L. McVay, R. R. Elnzider, G. L. Hofman, and L. C. Walters, "The Relationship between Carbide Precipitation and the In-Reactor Deformation of Type 316 Stainless Steel," $J$. Nucl. Mater. 73 (1978) 201-209.

21. F. A. Garner, E. R. Gilbert, and D. L. Porter, "Stress-Enhanced Swelling of Metals During Irradiation," Proceedings of the Conf. on Effects of Radiation on Materials, Savannah, Georgla, June 1980, pP. 680-697 (ASTY-STP-725).

22. E. H. Lee, P. J. Mazlasz, and A. F. Rowcliffe, "The Structure and Composition of Phases Occurring in Austenitic Stainless Steels In Therwal and Irradiation Environments," Droceedings of the symposium on phase stahility duming Imarlintion (ed. by J. R. Holl and, L. K. Mansur, and D. I. Potter, ThS-AIMR, 1981.

23. J. P. Foster, D. L. Porter, and Umesh P. Nayak, "Enhanced Irradiation Creep Deformation Due to Gradual Temperature Reductions," Westinghouse Report WARD-0X-94000-6 (to be subaltted to Joumal of Nuclear iatem(als). 
24. F. A. Garner, E. R. Gilbert, D. S. Gelles, and J. P. Foster, Effect of Teperature Changes on Swelling and Creep of AISI 316,Proceeding of Conf. On Effects of Radiation on Haterials, Savannah, Georgia, June 1980, Pp. 698-712 (ASThi-STP-725).

25. Hans J. Bergaann, Didier Haas, and Kornellus Herschbach, -Irradiation Induced Creep and Swelling of Cold-Worked W-Nr 1.4981 Irradiated in the Rapsodie Reactor," pp. 241-251 in Inter. Conf: Rad. Fff. in Breeder Reactor Structural Mater. Scotterlale, Amizonx, June 19, 1977 (ed. by M. L. Blelberg and J. H. Bennett) AIMF. Hew York, 1977.

26. E. Robert Gilbert and Artell J. Lovell, Tenperature Defendence of In-Reactor Creep of 207 Cold-Worked 316 Stainless Steel," pp. 269277 in Inter. Conf: Rar. Iff. in Breeder Reactor Structural Mater., Scottedale, Ariaona, Jume 19, 1.977 (ed. by M. L. Bleiberg and J. W. Bennett), AIrE, New York, 1977.

27. E. R. Gilbert and J. F. Bates, "Defendence of Irradiation Creep on Temperature and Atan Displacenents in $20 \%$ Cold-Worked Type 316 Stainless Steel,"J. Ruct. Mater. 65 (1977) 20، 209.

28. C. Hassilew, L. Anderko, and L. Schafer, Bestrahlungsinduziertes Kriechen Oberhalb $0.5 \mathrm{~T}_{5}$, bei Stabilisierten Austenitischen Stahlen," Proc. of the Conference on Imradiation Rehavior of Metallic Materials for Past Reactor Core Comoonents, Ajaccio, Corsica, Prance, Jume 1979, p. 419.

29. M. M. Paxton, B. A. Chin, F. R. Glibert, and R. E. Nygren, "Comparison of the In-Reactor Creep of Selected Ferritic, Solid Solution Strengthened, and Precipitation Hardened Comercial Alloys," $J$. pucl. Mter. 80 (1979) 144-151.

30. M. M. Paxton, B. A. Chin, and E. R. Gilbert, "The In-Reactor Creep of Selected Perritic, Solid Solution Strengthened, and Precipitation Hardened Alloys," ${ }^{\prime}$. Nucl. Mater. 95 (1980) 185-192.

31. J. Erler, A. Malllard, G. Brun, J. Lehwann, and J. M. Dupouy, Le C.smportement D'Acters Perritiques sous Irradiacion aux Neutrons Rapides, - Proce of the Conference on Imadiation Rehavion of Metallic Material.s for Past Reactor Core Components, 4faceio, Corsica, mance, June 1979, Pp. 11-16.

32. R. A. Ho1t, "Effect of Mlcrostructure on Irradiation Creep and Growth of Zfrcaloy Pressure Tubes 'n Power Resctors," $J$. Vucl. Mater. 82 (1979) 419-4:9.

33. R. P. Ibrahim and R. P. Holc, "Anisotropy of Irradiation Creep and Growth of Zirconiun Alloy Pressure Tubes," $\%$. Nucl. Mater. 91

(1980) $311-321$. 
34. Erik Rolstad, "In-Pile Heasurements of Zirceloy Creep and PCMI Deforation Comparetive Evaluation of Ten-Creep Correlations,Muct. Technot. 49 (1980) 481-491.

35. D. Hosedale, G. W. Lewthratte, G. O. Leet, and U. Sloss, -Irradiation Creep in the Dounreay Fast Reactor,- Nature 224 (1969) 1301-1302.

36. D. Hosedale, D. R. Harries, J. A. Hudson, G. W. Lewthwate, and R. J. McElroy, "Irradiation Creep in Fast Reactor Core Component Haterials," p. 209 in Inter. Conf: Rad. Iff. in Breeder Reactor Structural Mater., Scotterlale, Arizona, June 1.9, 1977 (ed. by M. L. Bleiberg and J. H. Bennett), AIMP. New York, 1977.

37. G. W. Lewthraite and D. Hosedale, The Effects of Temerature and Dose-Rate Variations on the Creep of Austenitic Stainless Steels in the Dounreay Past Reactor," J. Wucl. Mater. 90 (1980) 205-215.

38. L. K. Mansur and W. G. Wolfer, Reduction of Irradiation Creep by Point Defect Trapping," Proceedings of the Conference on Effects of Rarliation on Structural Materials, ASTM STP 683, J. A. Sprague and D. Rraner, eds., 1979, Pp. 624-639.

39. R. B. Jones and I. G. Crossland, Creep of Simple Nickel Alloys under Neutron Irradiation," Proc. of Imariation Behavior of Metallic Materials for Past Reactor Core Components, 'Supplement,' 4,iaccio, Corsica, Prance, June 1979, pp. 49-56.

40. J. F. Batcs, R. H. Powell, and E. R. Gilbert, "Reductions of Irradiation-Induced Creep and Swelling In AISI 316 by Composithonal Modifications," Proceedings of Conf. on effects of Radiation on Materials, Savannah, Georgla, June 1980, Pp. 713-734 (ASTH-STP-725).

41. R. R. Gilbert, D. C. Kaul1tz, J. J. Holmes, and T. T. Claudson, - Past Reactor Induced Creep in 207 Cold-Horked Type 316 Stainless Steel, Proc. RNF. Tonf. on Irradiation Smbrittlement and creen in Fuel Cladiing and Come Components, London, November 1972, pp. $232-251$.

42. J. M. Dupouy, J. Lehmant, L. Cartier, R. Huillery, and P. Millet, "Recent Deternination $r$. he Irradiation Creep Rate of Cold-Worked 316," pp. 229-241 in Int. . Conf: Rad. Bff. in Rreeder Renctor Stmuctumal Materialo, Seotrolale, Amizona, Tume 19,1977 (ed. by M. L. Bleiberg and J. H. Bennett), AIME, New York, 1977.

43. K. D. Close, K. Herschback, L. Schnidt, and H. Vanderboorn, "Irradiation Induced Creep Experiments in the BR2 Reactor UBing the Resonant Cavity Method," J. Nucl. Mater. 65 (1977) 244-249. 
44. K. Herschbach, R. Ehrlich, and E. Matenna, Tber das Kriechverhalten und der Mikrostruktur des Ferritischen Herkstoffes Nr. 1.6770 unter Bestrahlung," Proc. of the conference on Impariation Behavior of Matrilic Matemials for Past Renctor Cors components, A,iaceio, Corsica, mponce, June 1979, pp. $25-29$.

45. S. R. Mackwen and V. Fidleris, Verification of a Hodel for In-Reactor Creep Transients in Zirconfun,- Phil. Mag. 31 (1975) $1149-1157$.

46. S. R. Hackiren and V. Fidleris, "Irradiation Creep in Zr Single Crystals," J. puel. Mater. 66 (1977) 250-257.

47. S. I. Buckley and S. F. Manthorpe, The Induction of Creep by Charged Particle Irradiation,- Proc. BnES Conf. on Impadiation Fumittlement and Breep in Puel clarliting oul cove components, London, Novenber 1972, Pp. 253-258.

48. D. Calllard, J. L. Martin, and B. Jouffrey, "Creep under Irradiation of 316 Steel in the High Voltage Electron Microscope," Actr Het. 28 (1980) 1059-1067.

49. R. R. Vandervoort, H. L. Barnore, and A. K. Murkhergee, Tffects of High-Energy Neutron Irradiacion on the Creep of Nlobius," Rariation Iffects, 41 (1979) $113-114$.

50. S. D. Harkness, F. L. Taggee, and F. V. Nolfi, "Simulation of In-Reactor Creep of Type 304 Stainless Steel, Proc. BNiS Conf. on Immadiation mibrittlement and Greep in Puel, Tadiling and core Componente, London, November 1972, pp. $259-265$.

51. P. K. Hendrick, D. L. Michel, A. G. Pleper, R. E. Surrate, and A. L. Bewent, Jr., "Simulation of Irradiation-Induced Creep in Nickel," t. Vucl. Hater. 59 (1976) 229233.

52. P. L. Hendrick, D. L. Michel, A. G. Pleper, R. E. Surrate, and A. L. Bewent, Jr., "Ion-Simulated Irradiation-Induced Creep of Nickel," Proc. Int. Conf. on Radiation Rffects and Tritium rechnology for Pusion Renctors, CONP-750989, 1976, Vol. II, p. 84-117.

53. D. J. Michel, P. L. Hendrick, and A. G. Pleper, "Transient Irradiation-Induced Creep of Niclel during Deuteron Bombardwent," J. Nuct. Nater. 75 (1978) I-6.

54. P. L. Hendrick, "Light Ion Irradiation Creep Apparatus," Nucl. Instmuments and Methode, 161 (1979) 345-359.

55. C. I. Henager, J. L. Brimhall, and B. P. Simonen, "Creep in Nickel Bombarded with $17 \mathrm{MeV}$ Deuterons," T. NuCl, MatBr. 90 (1980) 290- 296. 
56. R. J. McElroy, J. A. Hodson, and R. S. Helson, -Irradiation Creep during 4 MeV Proton Irradiation,- Proc. Int. Conf. on Radiation Effects and Tritiu Technology for Fusion Reactors, Conf-750989, 1976, Vol. II, P. $72-83$.

57. J. A. Hudson, R. S. Nelson, and R. J. McElroy, The Irradiation Creep of Nickel and AISI 321 Stainless Steel during 4 HeV Proton Bombardent," J. Nucl. Mater. 65 (1977) 279-294.

58. P. Blanchard, P. Jary, and J. Delaplace, Etude du Pluage sous Irradiation par des Particules Alpha D'Aciers Inoxydables Austenit Iques Type 316 (172 Cr-132 Mi-22 Ho),-J. Tuei. Mater. 74 (1978) 267-276.

59. P. Jung, C. Schwaiger, and H. ollmaier, "Irradiation Creep in Deuteron-Bombarded Stainless Steel,- $J$. Wuel. Mater. $85 \& 86$ (1979) $867-871$.

60. Chr. Schwaiger, P. Jung, and H. Ullmaier, Irradiation Creep in Deuteron Bombarded Stainless Steel, $J$. Wucl. Mater. 90 (1980) $268-270$.

61. T. C. Relley, R. L. Auble, and R. H. Shannon, "Irradiation Creep under $60 \mathrm{HeV}$ Alpha Irradiation," $J$. Nucl. Mater. 90 (1980) 271- 281 .

62. S. K. Khera, C. Schwaiger, and H. U1lmaler, The Influence of Stress on the Early Stages of Void Pornation In a Hodel Stainless Steel," subnited to Joumal of nuclear Iateriats.

63. V. R. Sethi, A.P.L. Turner, and F. V. Nolf1, Jr., "Negative Irradiation Creep in Solution Annealed and Aged 316 Stainless steel," Proc. Conf. on Phase Stahility During Imarliation, AIML, PILtsburgh, 1980.

64. Johsel Nagakawa, V. K. Sethi, and A.P.L. Turner, "Irradiation Creep and Solute Segregation," Proc. Fonf. on Phase Stahility Duming Impaliation, AIME, Pittsburgh, 1980.

65. L. K. Mansur and W. A. Coghlan, Theoretical Relationships between Creep and Swelling by Point Defect Absorption during Irradiation," Proc. Tanarla Conference $V$ on Point Defects and Defect Intemetions in Metals, Kyoto, Japan, November 1981, to be published. 